\title{
> Elementos para a interpretação de Tempo de Espalhar Pedras, de Estevão Azevedo
}

> Elements for interpreting Estevão Azevedo's Tempo de Espalhar Pedras

por Ana Laura Malmaceda

Mestra em Estudos Brasileiros pela Universidade de Lisboa. Doutoranda em Literatura Lusófona e Francófona no programa de Romance Languages and Literatures em Harvard. E-mail: boenomalmaceda@g.harvard.edu. ORCID: 0000-0001-9168-7255.

\section{Resumo}

Este artigo analisa a poética da obra Tempo de Espalhar Pedras, de Estevão Azevedo, lendo nela estruturas de violência colonial presentes em práticas sociais brasileiras. A partir de uma reflexão sobre os arquivos cognitivos tocados pela narrativa, um exercício de diálogo com obras de diferentes genealogias da literatura brasileira do século XX é proposto, em especial com o que se passou a chamar de romance regionalista. Por fim, possíveis vertentes da obra de Azevedo surgem, num passeio por eixos temáticos do horizonte literário contemporâneo nacional.

Palavras-chave: Literatura brasileira. Estudos culturais. Estudos brasileiros.

\begin{abstract}
This paper analyzes social structures of kinship in Estevão Azevedo's Tempo de Espalhar Pedras, with special interest in colonial practices of violence and institutionalized discrimination present in this work. The narrative's social portraits are traced to historical and cognitive archives of Brazilian culture, with a special regard on what came to be known as the Brazilian romance regionalista. After this reflection, a broader exercise of dialogue is proposed, this time with narratives and possible classifications of Azevedo's work in a contemporary landscape.
\end{abstract}

Keywords: Brazilian literature. Cultural studies. Brazilian studies. 
Para ler Graciliano Ramos, talvez convenha ao leitor aparelhar-se do espírito de jornada, dispondo-se a uma experiência que se desdobra em etapas e, principiada na narração de costumes, termina pela confissão das mais vívidas emoções pessoais. Com isto, percorre o sertão, a mata, a fazenda, a vila, a cidade, a casa, a prisão, vendo fazendeiros e vaqueiros, empregados e funcionários, políticos $e$ vagabundos, pelos quais passa o romancista, progredindo no sentido de integrar o que observa ao seu modo peculiar de julgar e de sentir. De tal forma que, embora pouco afeito ao pitoresco e ao descritivo, e antes de mais nada preocupado em ser, por intermédio da sua obra, como artista e como homem, termina por nos conduzir discretamente a esferas bastante várias de humanidade, sem se afastar demasiado de certos temas e modos de escrever.

Antonio Candido, Literatura e confissão

Tomando como inspiração o espírito de Antonio Candido ao pensar pela escrita a experiência de leitura da prosa de Graciliano Ramos, para ler Tempo de Espalhar Pedras, do escritor potiguar Estevão Azevedo ${ }^{1}$, talvez convenha ao leitor preparar-se para uma jornada na qual, dispondo-se a uma experiência que se desdobra em etapas, deverá mergulhar em costumes já demasiado distantes, mas nela encontrará, mesmo na mais completa escassez de humanidade e na aridez do solo, mesmo na brutalidade como regra, substâncias afetivas universais. Os tipos desta narrativa são aqueles das veredas, mais especificamente das regiões que passaram pelo processo de exploração de pedras preciosas, como a Chapada Diamantina, no centro da Bahia, ou locais do ciclo do ouro em Minas Gerais: o coronel paternalista, os jagunços, os cabras que vivem de cavar e peneirar o que encontram nos jazigos minerais, as famigeradas mulheres-damas (expressão retomada pelo exercício de arqueologia lexical do

\footnotetext{
${ }^{1}$ Estevão Azevedo, Tempo de Espalhar Pedras, 2014.
} 
autor), o comerciante local, o escravo forro, as donasde precárias casas, o padre. Sem data ou ambientação precisas, quase totalmente isolada, a vila onde se dá a narrativa não tem nome, mas representa uma composição social recorrente na história do Brasil, a da "febre do ouro" (aqui, do diamante) e de suas consequências, além dos costumes, do jeito de um sertão recriado, seus dilemas estruturais facilmente encontrados na realidade exterior à prosa, e os conflitos caleidoscópicos vividos por aqueles que foram brutalizados pelo espaço físico e social no qual sobrevivem.

Procuro aqui ler Tempo de Espalhar Pedras com enfoque em questões de estilo, contextualização na paisagem da literatura contemporânea e representação social do Brasil. Ao tecer esta análise, será complementar o olhar para obras regionalistas que retratam a permanência de um território nacional alegórico, arcaico e isolado, construção simbólica da qual o autor parte. Também serão tratadas as representações sociais que pensam sobre dinâmicas de violência no Brasil, tanto no que há de local quanto no que há de universal nos conflitos de poder. A narrativa de Azevedo nos desafia a pensar numa retomada da paisagem da chamada segunda fase do modernismo brasileiro; desta forma, tento refletir, em diálogo com críticos que vêm construindo uma base teórica acerca da produção recente de literatura brasileira, sobre o lugar dessa poética na contemporaneidade.

Começo, então, a escavar.

O que há nas veredas para além de Deus, o sem-nome e um sem-número desejos? Na terra fictícia riscada por Estevão Azevedo, que provavelmente situase entre o fim do século XIX e o início do XX, não há sede, como acontece 
ciclicamente, por exemplo, em Vidas Secas, de Graciliano Ramos. E não há uma jornada metafísica, como em Grande Sertão: Veredas. Mas, correndo o risco de mimetizar a prosa do livro, não carece. Azevedo fortificou seus traços nas arestas de cada personagem, esboçando esporádicos sinais de tentativas de ternura, fundamentados numa estrutura trágica, na qual o colapso é sugerido como destino desde o princípio da narração. Fosse um ecossistema, a aldeia estaria em ponto de extinção.

Os desejos não levados a efeito e a decorrente privação de vontades variadas e agudas são a seca desse romance. Talvez por este motivo a história comece já no seu fim: os homens que lá vivem já conheceram a glória do encontro com grandes diamantes, e no presente narrativo precisam se contentar com pepitas tão raras quanto modestas. Frustrados com o fim da possibilidade jamais alcançada de enriquecimento, resta a eles o reajuste de seus planos de modernidade, voltando à miséria e a cultivos esquecidos, como o da plantação para subsistência e a caça. A ruína do vilarejo, voltado para a extração de diamantes, é previsível desde a primeira página, quando a dona de casa Vitória, ao pensar sobre Gomes, seu marido e agressor, sentencia: “Sabia - e por isso, na sala, o pequeno altar em que nunca se apagaria a vela, mesmo que há dias não visse chama o fogão, por garimpo fracassado -, sabia aonde a busca por diamantes os levaria. O marido, não"2 . Pelos traços de lucidez e perspicácia, Vitória faz lembrar a figura de Sinha Vitória, de Vidas Secas, a mulher que, apesar de ser mantida em condição de invisibilidade e mudez face ao poder patológico de linhagens coloniais, sustenta sem alarde a vida de um espaço, compensando

\footnotetext{
${ }^{2}$ Estevão Azevedo, Op. Cit., 2014, p. 1.
} 
em mátria a imposição traumática de uma pátria genocida.

Os patriarcas da comunidade respondem ao desmoronamento de sua economia negando o fim do ciclo. Permanecem em inércia, esperando a próxima pedra que os dará algum tempo longe da miséria que, sistêmica, é sentida como cíclica. Imersos em seus desejos, ocupam-se com conflitos internos, ainda habituados às disputas de uma terra sem lei e com tamanha riqueza. No momento em que as pedras já pararam de surgir, um dos garimpeiros da vila, o senil e devoto Silvério, em meio a um delírio de fé e fome, tem uma visão que julga divina: buscar diamantes no solo da própria casa. A hipótese passa a ser copiada pelas outras famílias, que replicam a atitude desesperadora e submergem num delírio de predestinação. A última chance de sobrevivência da aldeia é, portanto, a autodestruição. O contexto é pano de fundo para conflitos entre sujeitos incapazes de estabelecer interações sociais sem violência e desconfiança.

Quando se trata de um recurso tão valioso quanto o da mineração de pedras preciosas, é recorrente que o encontro da riqueza natural com o homem movido pelo capital gere um ciclo de violência e caos vertiginosos, destruindo a possibilidade de laços sociais estáveis. Até o encontro com a última pedra, passa a ser contada uma história de cobiça, na qual disputas estão, assim como as pedras, em estado bruto, sem a lapidação de um pacto social. Torna-se, portanto, um empreendimento colonial sem freios. Exemplo recente na história nacional é Serra Pelada, na região Norte do Brasil. ${ }^{3}$ Orientando-se pelos

\footnotetext{
${ }^{3}$ Até hoje explorada em minério de ferro, a região viu em poucos anos, cessando apenas com a proibição da prática do garimpo, nos anos 1980, uma corrida de 80 mil homens de todo o país em busca do milagre da fortuna rápida. Serra Pelada ganhou registro definitivo nas fotos de Sebastião
} 
casos sobre garimpo passados em território nacional, criar uma narrativa sobre o tema parece exigir que a ganância e o individualismo tomem lugar central. Ao escolher a fase final de um ciclo de destruição que já teve dias mais prósperos, o autor pode tratar apenas da cobiça, sem possibilidade de realização.

Na ficção sobre o sertanejo, Deus é homem versátil e prenhe de verso, uma cosmovisão confundida com os elementos vistos pelos filhos do Novo Mundo. A forte carga religiosa está impregnada em provérbios e principalmente na história de Silvério, um retrato da desvirtuação da fé. A presença da religião é tamanha que acredito ser possível designar para cada personagem um dos sete pecados capitais do cristianismo - talvez como guias para a construção desta Torre de Babel. Por crer nas bonanças que Deus lhe trará, pois no caminho da fé não há espaço para dúvida, o senil Silvério pode ser lido como uma alegoria da preguiça. Vive sem qualquer cultivo que não seja o do milagre, a busca por um diamante que o salvará. Não cultiva nem o que a terra dura e seca é capaz de oferecer. Acaba, assim, por balizar seu convívio social pela gula quando alguém lhe oferece algo, incapaz de criar formas de alimentar a si mesmo. No caso de Joca, filho de uma numerosa família de garimpeiros, ao encontrar Bezerra, alguém que, diferente dos familiares, o reconhece em sua humanidade, recebe este pouco como muito, e acaba por embaralhar-se entre vários tipos de amor, fazendo um arriscado garimpo ilícito no vilarejo com seu cúmplice. Quando finalmente, depois de ser rejeitado por Bezerra, vê-se fora do véu da projeção,

Salgado, cujo olhar explicita o espanto diante da empreitada humana na região: um formigueiro humano pintado de lama, subindo e descendo escadas precárias de uma montanha desmatada, feita de homens levando grandes sacos de terra na cabeça, com formas semelhantes às da Torre de Babel. Até o fim das toneladas de ouro disponíveis, nem o próprio governo foi capaz de retirar os famintos pelas pedras de Curionópolis (PA), cidade fundada e nomeada em homenagem ao Major Curió, militar que se tornou "coronel interino" daquelas terras. 
inverte paixão em cólera e cultiva a soberba, ao acreditar que, denunciando o exparceiro de negócios ao coronel da cidade, conseguirá assassiná-lo e livrar-se do crime que cometeu como cúmplice, a venda de pedras a compradores estrangeiros. A única mulher vista com atenção na obra é Ximena, filha de Gomes e Vitória. Com Rodrigo, filho de uma família que guarda rivalidades com a de Ximena, mantém uma relação de ódio até o tato, único lugar possível de acordo entre os dois. Num abrigo forjado nas matas, constroem um refúgio sem outros símbolos que não os de uma superfície plana, tentativa de cama, onde o afeto existe entre luxúria e ira. A avareza veste bem o senhor Aureliano, coronel da cidade, que, por motivos que ninguém na vila ousa indagar (Deus é, afinal, um pai, um patriarca, um regime, uma lei apenas questionada no seio de si), tem muito mais do que precisa e sempre gostaria de ter mais. Por fim, a inveja mostra-se o epicentro da economia libidinal dessa atmosfera, que ocorre em diversas situações: quando alguém tem dias de folga ou adquire um bem material em decorrência do encontro de uma pedra; ou mesmo na forma de ciúme, no caso de Sancho, um dos jagunços da vila, que mata sua esposa, a índia Botocuda, ao descobrir que ela havia sido estuprada.

\section{Questões de estilo literário e a retomada do romance regionalista}

Se contarmos com as consequências de cada uma das histórias citadas acima, o pecado que origina muitos desses conflitos está na tentativa de reverter certas faltas, sejam elas materiais ou afetivas. Pecar é desejar fora do código de honra (conflito que será tratado mais à frente) e do sistema de desigualdade que atinge os garimpeiros, análogo à escravidão. O narrador desse romance nos leva 
ao centro das pulsões de cada personagem, pegando emprestados sentimentos de pedra, vividos de forma aguda, mas pouco refletidos por cada personagem, como material para recriar de forma aproximada seu corpo de experiências e sentidos. Possíveis de serem colocados em linhas simples, cada caso de conflito e cada ação decorrente dele não surgem como surpresa; o processo de associação de pensamentos de cada personagem é trabalhado com proximidade aguda pelo narrador, que traduz, aproxima, e reorganiza a paisagem pela literatura. Há um acordo entre a vida material e afetiva das personagens.

Os caminhos associativos da psique de cada personagem são construídos pelo discurso indireto livre. É precisa a forma com a qual Azevedo esmiúça o campo interno e externo das personagens, sensível ao humano e ao social, aproximando-se deles com escuta atenta aos gestos. Neste ponto podemos facilmente interligar Tempo de Espalhar Pedras a Vidas Secas, de Graciliano Ramos, pois o desenho das personagens é muito semelhante, não só de sua forma cognitiva, trabalhada por meio do recurso discursivo escolhido, como também na opção por um romance fragmentado em capítulos que intercalam pontos de vista, recorte presente nas duas obras, que dá às narrativas ritmo e atmosfera visual semelhantes ao roteiro cinematográfico. Por mais que sejam brutos como pedras, os personagens não são brutalizados pelo narrador. Suas decisões, sempre centradas na autodefesa, pinceladas às vezes com um desejo obliterado de afeto, ganham justificativas líricas, escavadas numa matéria subjetiva que as justifica. Muitas vezes, ao apresentar um conflito ou um traço que caracteriza um personagem, o autor utiliza metáforas com alusões à natureza e aos elementos do entorno, na paisagem e universo do sertão brasileiro: 
[...] como a água na cachoeira moldando a rocha instante a instante, imperceptivelmente, Isaldina, cada vez que entrava ou saía da sala e mirava o rosto dos filhos, convencia-se, sem o perceber, de que Rodrigo era o primogênito 4 .

A estrutura da narrativa é fragmentada, sendo cada um dos capítulos numerados, a apresentar uma cena com foco em uma personagem - são raras as que não terminam sem conflito ou presságio de morte. A prosa de Azevedo lança mão de diversas figuras de linguagem para aproximar seu narrador indireto livre às personagens, utilizando resquícios da linguagem oral para dar palavras aos que não são capazes de articular impressões, restritos apenas às palavras de pedra. As consequências da falta do domínio da linguagem para os moradores da vila geram desentendimentos fundamentais, frustrantes ao leitor pelas consequências violentas geradas no impasse verbal. Uma atmosfera de suspense emerge, fazendo da leitura uma experiência angustiante, na qual espera-se que, a qualquer momento, alguém seja vítima da forma de vida predatória do garimpo, como na seguinte sentença: "O ruim encobre o bom, mesmo em menor quantidade. Isso porque o que é mais valioso é mais frágil e dura menos" ${ }^{5}$. Por vezes, uma atitude de amor é confundida com ofensa, como no caso de Joca, que toca o rosto do parceiro de negócios, Bezerra, ajeitando uma mecha de seu cabelo. O drama entre os dois começa por um contato homoerótico muito sutil, entretanto enorme em face ao código de honra local. A partir daí, pela falta de palavras, Joca tenta retomar a proximidade com

\footnotetext{
${ }^{4}$ Estevão Azevedo, Op. Cit., 2014, p. 29-30.

${ }^{5}$ Ibidem, p. 272.
} 
Bezerra deixando cada vez mais resquícios de amparo, rejeitados com força. Para entender tamanha falta de sincronia entre intenções, o discurso indireto livre faz a ponte entre universo subjetivo e realidade social. Assim como em Vidas Secas, a opressão linguística marca uma economia libidinal precária. Tenho em mente Fabiano, o pai da família, preso por não conseguir defender-se através do discurso. Quando há violência, há também a seca da palavra.

A exaustão da economia material e libidinal da comunidade se dá em desentendimentos verbais generalizados. Joca e Bezerra simbolizam a fragilidade do afeto, reino do feminino, sempre considerado um perigo ou uma fraqueza para quem o sente. Já presente em Nunca o Nome do Menino, primeiro romance do escritor, o estilo lírico parece ser, em Tempo de Espalhar Pedras, transportado para o contexto rural, no qual ganha figuras de linguagem do léxico sertanejo, numa tentativa de reconstruir suas formas de pensamento e cosmovisão. Podemos apontar nesse sentido indícios do barroco, marca tão profunda na literatura de língua portuguesa, tanto em relação à prosa quanto à poesia: predominam os verbos conjugados em mais-que-perfeito, as metáforas, as sinestesias, os anacolutos e as prosopopeias. O autor não é econômico em sua prosa, carregada de metáforas e marcas de oralidade, como no seguinte trecho, no qual sua literatura flerta com o mito: "O rio dava o exemplo: seca e faz que morre, mas não morre, volta a correr, o mesmo rio. O rio, então, só pode de ser as margens" ${ }^{\prime \prime}$.

Azevedo retoma a valorização da linguagem oral através de sua estilização, outra semelhança com a geração de 30, que a fabricava com precisão

\footnotetext{
${ }^{6}$ Ibidem, p. 125.
} 
técnica, fruto de uma educação de Engenho, em vastas pesquisas de léxicos próximos e distantes, buscando o Brasil. O uso de provérbios, outro traço universalista da obra, lembra em muito Grande Sertão: Veredas (1956). Isto porque busca por uma forma de aproximação entre o popular e o erudito, imbuindo-se dos elementos existentes daquele a quem desenha - neste caso, o sertanejo - para construir uma história de sintaxe ritmada, mesmo que mais concisa quando comparada ao clássico modernista.

Levando em consideração elementos de temática e estilo, pode-se dizer que o tipo de narrativa que presente em Tempo de Espalhar Pedras encaixa-se no que Alfredo Bosi chama, tomando como exemplo as obras Vidas Secas, de Graciliano Ramos, e Grande Sertão: Veredas, de Guimarães Rosa, de cultura criadora individualizada, caracterizada pela dialética entre a cultura erudita brasileira, centralizada no sistema educacional, e a cultura popular. ${ }^{7}$ Nela estão incluídas narrativas que "nunca poderiam ter-se produzido sem que seus autores tivessem atravessado longa e penosamente as barreiras ideológicas e psicológicas que os separavam do cotidiano ou do imaginário popular" ${ }^{\prime \prime}$.

O tratamento aos personagens assemelha-se muito, também, ao que Antonio Candido aponta em Graciliano Ramos ao afirmar que:

[...] à força com que transcende o realismo descritivo, para desvendar o universo mental de criaturas cujo silêncio ou inabilidade verbal leva o narrado a inventar para elas um expressivo universo interior, por meio do discurso indireto; a superação do regionalismo e da literatura empenhada, devida a uma capacidade de generalização que engloba e transcende estas dimensões e, explorando-as mais fundo do que os seus

\footnotetext{
${ }^{7}$ Alfredo Bosi, Dialética da colonização, 1992.

${ }^{8}$ Ibidem, p. 343.
} 
contemporâneos, consegue exprimir a "vida em potencial"9 .

O exercício de dar palavras aos que "não as têm", escavando a "vida em potencial", e, com isso, criando uma visão mais humana de homens brutalizados pela subalternidade, pode ser sentido com nitidez na construção de Gomes, pai de Ximena, que busca resistir ao desejo edipiano pela filha:

Perigava mergulhar, extrapolasse esse pensamento, outra vez no abismo parao qual a imagem de Ximena o atraía. Para evitar a arapuca, Gomes forçava o burro que carregava suas elucubrações para o lado oposto: em vez de deixar o pensamento conferir a todas as mulheres o atributo de fêmea, o que tornaria sua relação com elas menos variável e, portanto, menos complexa, Gomes, sem o perceber, conferia a todas elas o atributo de crianças da sua prole. [...] Como se fosse pai, sofria ao lembrar-se das mulheres do prostíbulo ao pensar em como viveriam num tempo em que os homens não encontravam nem sequer um diamante que lhes possibilitasse a manutenção de hábitos fundamentais como os que garantiam às coitadas a sobrevivência ${ }^{10}$.

\section{Representação da sociedade brasileira e código de honra}

No enredo do garimpeiro Rodrigo, centrado na relação de desejo puramente físico por Ximena, o autor afirma ter pego emprestado o conflito central do romance Abril Despedaçado, de Ismail Kadaré, sobre um vilarejo albanês dos anos 1930, no qual há um conjunto de leis não escritas intitulado Kanun, que impõe vinganças para assassinatos, obrigando a família que perdeu um de seus membros a tirar a vida de alguém da família do algoz. Inicialmente, Rodrigo resiste em assassinar o pai de Ximena, que ofende a honra de Diogo, patriarca da família de Rodrigo, publicamente. O motivo primário para adiar o

\footnotetext{
${ }^{9}$ Antonio Candido, Fiç̧ão e confissão, 2006, p. 147.

${ }^{10}$ Estevão Azevedo, Op. Cit., 2014, p. 173.
} 
assassinato de Gomes é a previsível perda do afeto sexual que estabeleceu com a filha do garimpeiro. Assim, o conflito desenhado na família circunda em torno da desonra, a perda do único valor que um homem pode ter no contexto do vilarejo. Essa configuração transparece o código dehonra fundamentado para estabelecer a mínima ordem na comunidade:

Do escravo ao roceiro, do capataz ao coronel, todos defendiam que, a uma vítima, sempre outra do lado oposto sucedia, e que aceitar sua vez nessa cadeia interminável de tocaias, escaramuças e duelos era dever de honra, não importava em que margem do rio rubro se estivesse ${ }^{11}$.

Por que a lei do Talião baliza as relações entre homens e o que ela representa? Cito um trecho da resenha de José Luiz Passos sobre o livro, que sugere o código de honra como uma das representações de dinâmicas sociais brasileiras encontradas na obra:

[o romance] nos revela uma face incômoda do nosso Brasil de agora: a paisagem é consumida até virar pó, a indígena é desumanizada, a honra desfeita é motor ridículo da comunidade [...] Quem ler, verá um pouco de hoje, muito embora a matéria esteja ancorada em chave mítica, em tempo remoto, prometendo um futuro bem menos que perfeito, no qual buscamos novas pedras ${ }^{12}$.

Os dilemas sociais da vila parecem, de início, elementos de composição de um quadro antigo. Numa leitura mais atenta, entretanto, é possível perceber que eles fazem jus aos modos de colonização e criação do território ao qual

\footnotetext{
${ }^{11}$ Ibidem, p. 192.

${ }^{12}$ José Luiz Passos, Romance de Estevão Azevedo traz faces de um Brasil desumanizado, 2014.
} 
chamamos de brasileiro. $\mathrm{O}$ código de honra serve como um ato fundador do projeto de exploração colonial, ainda presente na estrutura social do Brasil, país que registra um linchamento por dia, que carrega arquivos cognitivos de extrema violência recalcados em suas estruturas afetivas. ${ }^{13}$

Voltando à referência histórica da febre do ouro tardia no Brasil, é comum que o enriquecimento rápido leve um homem simples, sem contato com os centros de poder, a derramar fortunas nos prazeres oferecidos na própria terra, como a prostituição e o álcool, que chegam com a fundação da cidade. Um homem que não conhece nada além da falta passa, de forma repentina, a ter mais do que pudera almejar, mesmo que a fortuna vá assim como chega. O caso de Serra Pelada ficou conhecido por essa rápida marginalização urbana: casas de prostituição, bares e comércio de drogas e ouro alimentavam a cidade recémformada, na qual eram vertiginosamente inflacionados os valores de serviços e os alimentos para os padrões aquisitivos de cabras milionários. Entretanto, a vida dos novos ricos não valia uma pepita, por menor que fosse. Assassinatos eram frequentes: sem Estado, sobrevivia o código do talião, e o ditado popular cada um por si, Deus contra todos acabou por resumir o contexto da empreitada. Pedras preciosas deixavam homens pobres ricos por um dia. Ao chegar nas mãos dos centros que compram as riquezas, tudo volta ao arranjo habitual de trabalho disciplinado e desigualdade controlada. O microcosmo da vila sem nome guarda características sociais amplamente representadas e descritas na história do país. A organização social que estrutura o romance reflete as formas com as quais o poder se molda no Brasil. Sua base, desde o início, é a violência. Tomar a

\footnotetext{
${ }^{13}$ José de Souza Martins. Linchamentos: a justiça popular no Brasil, 2015.
} 
liberdade, a natureza e os corpos de outros homens para o acúmulo de alguns é o início do que veio a ser chamado de Brasil. ${ }^{14}$

Por onde começa o poder na vila de Tempo de Espalhar Pedras? Inicia-se pelo desconhecido exterior; os homens que passam para levar as pedras para onde elas podem ser usadas, manufaturadas, postas em corpos femininos, mãos masculinas. Da vila para fora dela, o valor de cada diamante se multiplica. Não sendo uma potência industrial, o Brasil também se assemelha à vila imaginária. Hoje exporta minério, petróleo bruto e soja, e antes exportou café, exportou borracha, exportou ouro, exportou açúcar, exportou madeira. Representantes da coroa portuguesa foram enviados ao país para serem líderes máximos de Capitanias Hereditárias, sem que as terras fossem legitimamente suas, mas tendo de desenvolvê-las com recursos próprios. O donatário, homem colonial central e clássico, tinha plenos direitos de aplicar a justiça, e poderia sentenciar pena de morte a qualquer um que vivesse em suas terras. Por mais que quase nenhum dos designados tenha sucedido na empreitada, a figura patriarcal colonialista permaneceu nos coronéis do Nordeste, nos senhores de engenho, assim como nos homens que têm em líderes acima da lei a imagem projetada do poder. Aureliano é um deles. Sua face perversa e avarenta é intercalada por outra, tenra, autora de concessões graciosas, o retrato aguçado do paternalismo. Os homens que se doam de forma contínua e devota, mas sem demasiados elogios, ganham a última posição de poder disponível na estrutura de poder masculino. Os jagunços tornam-se a força que aplica a lei das vontades do senhor e a sua proteção. Abaixo, cheios de cobiça, restam os que foram atraídos

\footnotetext{
${ }^{14}$ Marilena Chauí, Mito fundador e sociedade autoritária, 2000, p. 62.
} 
às terras pela promessa já quase inexistente de riqueza rápida. Eles ainda produzem a riqueza e nutrem a vida que conseguem, mesmo que nela nasça quase sempre a falta. Mal são donos dos próprios corpos, os garimpeiros. Estão atados ao senhor das terras em condição semiescrava. Mas ainda há lugar menos côncavo e mais fundo a ser habitado nesse cenário. Abaixo de todos estão as mulheres - daí, talvez, a falta de representação feminina no romance -, que procuram apagar traços da própria existência feminina no intuito de se preservarem vivas em campo patriarcal. O código de honra parece ser o simbólico psicanalítico que equilibra essa estrutura desigual, que traz um discurso edificante a quem nada tem e nutre a violência como uma forma de defesa, como um valor positivo.

Sobrinho de Aureliano, o personagem Antônio mostra outra face universal e incorporada de forma intensa na ficção brasileira do período da redemocratização, nos relatos de não-ficção e na prosa memorialista da luta armada, a do torturador. O momento em que Antônio tortura Joca retrata o nascimento da possibilidade de perversão no poder autoritário. Antônio é considerado um covarde pelos habitantes da vila, alguém que, se tivesse de viver por conta própria, jamais seria um líder. Entretanto, mesmo desprovido das qualidades atribuídas aos ideais masculinos, ele encontra outra forma de legitimar seu poder, o descobrindo na tortura psicológica. Assustados, os jagunços acabam por vetar a ação de Antônio, interrompendo seu assustador método, pondo fim à vida de Joca, cessando a tortura. É neste ponto que se estabelece o limite do código de honra local: matar, sim; torturar, não. Vê-se em reflexo, no canto do quadro, a perversão do pensamento autoritário brasileiro, criador de máquinas de tortura e esquecimento muito mais engenhosas em sua 
brutalidade do que qualquer contexto de pobreza.

A ordem, aos moldes traçados anteriormente, é o revés de todos no vilarejo. Dentro das casas o perigo não é tão eminente quanto na rua, outra característica que reflete a organização da paisagem urbana brasileira. No capítulo catorze, sobre Silvério, há uma história que sutilmente simboliza a atmosfera da vila em declínio: "Que autoridade tinha o padre para impedir, se se abstivera de exorcizar o velhote possuído que imaginava matar a vila toda com arma que nem empunhava, e que eles, os pecadores, é que tiveram de salvar?"15, pergunta-se o narrador. A morte, nesse romance, sempre deixa alguém a ser vingado, tornando-se predatória, sugerindo um ciclo de violência que se reproduz. Parte do perigo de circular nesse espaço ficcional é mostrar-se emissor e feitor de qualquer afeto. O princípio de conduta pessoal a ser valorizado é baseado no silêncio, na contenção dos sentidos. Ser como pedra ao ser quebrada pela raiva há muito lapidada. Sábio é o que entende o seu lugar, e se conforma. Assim, é nas sutilezas que a vontade de humanidade se revela. No caso de Bezerra, citado no início do artigo, o afeto que se reflete de forma involuntária reluz na escolha pela vida de Joca.

\section{Possível classificação do romance na literatura contemporânea}

Enquanto boa parte da produção brasileira contemporânea escolhe as grandes cidades e o distanciamento de temas já canonizados pela arte ligada à identidade nacional, tratamos aqui de um romance rural, ausente de

\footnotetext{
${ }^{15}$ Estevão Azevedo, Op. Cit., 2014, p. 109.
} 
personagens intelectualmente instrumentalizados, não centrado em conflitos próximos para os leitores de centros urbanos. Tempo de Espalhar Pedras retoma as narrativas regionalistas da geração de 30, dá continuidade à produção de escritores como Rachel de Queiroz e Herberto Sales, este último autor de Cascalho.

Tempo de Espalhar Pedras apresenta um desafio de classificação no contexto atual da literatura brasileira. Não é possível enquadrá-lo, por exemplo, na divisão da literatura exigente, sobre a produção mais transgressora e experimental de autores como Nuno Ramos, Laura Erber e Juliano Garcia Pessanha, desinteressada em chegar a grandes ou mesmo médios públicos. ${ }^{16}$ Não é residual, nem utiliza um narrador desconfiável ou desconfia do ato de narrar, características apontadas por Leyla Perrone-Moisés. Entretanto, há um elemento de pluralidade narrativa no qual é identificada com frequência a produção contemporânea. ${ }^{17}$ Cito o escritor Luiz Ruffato, em ensaio sobre a condição da literatura contemporânea brasileira e suas possíveis classificações: “Acentua-se uma tendência que vinha da década de 1970, de ausência de movimentos, correntes ou filiações estéticas: cadaum é sua própria escola"18. Partindo desse princípio, que incorpora a pluralidade como característica, o romance de Azevedo talvez encontre um local em seu contexto histórico. Outro ponto fundamental para justificar o aparecimento de um romance como o de Azevedo é que o tema do regionalismo vem sofrendo intervenções desde o seu surgimento, mas jamais foi abandonado - autores de destaque na produção dos

\footnotetext{
${ }^{16}$ Leyla Perrone-Moysés, A literatura exigente: os livros que não dão moleza ao leitor, 2012.

${ }^{17}$ Beatriz Resende, Possibilidades da nova escrita literária no Brasil, 2014.

${ }^{18}$ Luiz Ruffato, Alguns apontamentos sobre a literatura brasileira contemporânea, 2013.
} 
anos 1990 e 2000 como Milton Hatoum e Luiz Ruffato escolheram o regional como cenário para seus romances. ${ }^{19}$

Os destinos trágicos de quase todos os personagens, assim como seus sentimentos de pedra, com fé na violência do código de honra, fabricam nessa história um alto nível de brutalidade e tensão. Ela é tamanha que, contrastada com a escassez de compaixão, constrói uma história sem efeito exato de verossimilhança. Talvezisso sinalize uma escolha, voluntária ou não, de fuga do neorrealismo do romance regionalista, ao dar alicerce à sua obra como um outro tipo de ficção, dedicando maior atenção à alegoria da ganância, sem a busca por uma representação social fidedigna.

Em ensaio sobre a produção literária brasileira pós-1995, a crítica literária Beatriz Resende compreende três fluxos nos quais passam a literatura dos últimos vinte anos: uma produção mais democrática e plural, características englobadas pela instituição de um sistema mais partilhado do campo artístico, que propõe a reconfiguração do campo da literatura, abrindo-o para novas artes e novas vozes (a); o deslocamento da questão nacional, em confluência com o contexto da globalização (b); a evasão do realismo formal, não em caminhos já reconhecidos de literatura, como o real-imaginário na contexto latino-americano, mas no que chama de "rasura do real" (c). Segundo a autora, a representação realista hoje é menos comprometida com o real, e suas fronteiras estão dissolvidas pela entrada, por exemplo, do documental e de outras linguagens artísticas, como a fotografia. ${ }^{20}$

\footnotetext{
${ }^{19}$ Karl Erik Schøllhammer, Ficção Brasileira Contemporânea, 2009, p. 79.

${ }^{20}$ Beatriz Resende, "Possibilidades da nova escrita literária no Brasil", 2014.
} 
Ponto em comum ao conceito cunhado por Resende é o que Erik Schøllhammer chama de presentificação não representativa da realidade, referindo-se em específico à literatura regionalista:

É preciso questionar o privilégio do realismo histórico como "janela para o mundo" [...] a fim de entender de que maneira a literatura contemporânea procura criar efeitos de realidade, sem precisar recorrer à descrição verossímil ou à narrativa causal e coerente ${ }^{21}$.

Mesmo no século XXI, no que poderia ser chamado em associação livre de pós-pós-modernismo, a obra de Azevedo pode ser entendida como um sinal de que o homem urbano ainda sonha com o ato fundador de seu mundo, mesmo que não o narre nos mesmos termos.

Ao dar destino de revés a todos os personagens, Tempo de Espalhar Pedras evita que a tragédia social seja remediada pela ficção, sem espaço para o romantismo habitual dado, por exemplo, em certas narrativas históricas sobre senhores e escravos, nas quais as relações pessoais do sistema patriarcal prevalecem, ou ao menos se apresentam como possibilidades de ascensão social, mantendo relações cordiais. A ideologia meritocrática de superação das dificuldades por meio da perspicácia ou outras qualidades pessoais do personagem subalterno também é inexistente no romance. E, ao contrário de Vidas Secas, livro que desperta a compaixão pelos protagonistas e cuja carga política nutre a dicotomia entre trabalhador e explorador, em Tempo de Espalhar Pedras não há heróis. Nesse sentido, cito Jaime Ginzburg, num ensaio em que

${ }^{21}$ Karl Erik Schøllhammer, Op. Cit., 2009, p. 79. 
sinaliza na ficção contemporânea a escolha de personagens que representam minorias, assim como novas abordagens da produção contemporânea à história, reescrevendo-a:

A construção estética não mimética seria importante, nessa perspectiva, por atuar dentro do campo dos conflitos históricos. Obras literárias podem corresponder a intervenções de resistência, na medida em que constituem interpretações da História a partir de lugares de enunciação diferentes dos que estão estabelecidos como aceitáveis pelas instituições de controle social. Dar voz a um personagem excluído da família, incestuoso e talvez epilético, e a um guerrilheiro torturado, atormentado por memórias dolorosas, são escolhas por parte dos escritores que supõem abandonar as condições de percepção habituais do cotidiano, dos discursos midiáticos, das instituições de controle político e jurídico ${ }^{22}$.

Ginzburg também enxerga uma busca da produção contemporânea por caminhos alternativos para as narrativas centralizadas em figuras patriarcais, modelo que "prioriza homens brancos, de classe média ou alta, adeptos de uma religião legitimada socialmente, heterossexuais, adultos e aptos a dar ordens e sustentar regras"23. O que se tem em Tempo de Espalhar Pedras é a estrutura da sociedade patriarcal brasileira oitocentista, o que deveria ser o oposto ao que Ginzburg sinaliza como tendência da produção contemporânea. Entretanto, mesmo que a presença patriarcal seja forte, muitos dos assuntos tratados no romance de Azevedo são bastante contemporâneos e, por isso, talvez possam ser incluídos na classificação temática de Ginzburg, que abrange os temas de minorias: violência doméstica, limites da competição social,

\footnotetext{
${ }^{22}$ Jaime Ginzburg, "O narrador na literatura brasileira contemporânea”, 2012, p. 201.

${ }^{23}$ Ibidem, p. 200.
} 
homossexualidade.

Portanto, no campo do interstício o localizo. Não cabe a um escritor fabular tendo em mente classificações do presente, porque o trabalho está justamente no que não é dito, captado fora do que poderia ser pensado em termos conceituais. Ouvir o presente, nessa narrativa, é imaginar a ruína do projeto moderno. Neste caso, sem um futuro redentor.

Tempo de Espalhar Pedras cria um universo literário no qual, em estilo de maturidade precoce, habitam em nova vida o regional, o pitoresco e o universal. Consegue, assim, narrar uma história de forte tom lírico, na qual projeta sombras da modernidade brasileira e da sua violência fundadora. O texto robusto, confiante no projeto estilístico criado, também captura retratos humanos precisos, nos quais é possível enxergar algo dos limites e da essência do desejo a vivacidade dessas imagens advém em muito do processo associativo dos personagens, versado de forma acurada, cadenciada em nuance e traço firme. Ao escolher uma história de cobiça como a do garimpo no Brasil e subir o tom do conflito de um microcosmo imaginado, dando a ele um rígido código de honra, o autor constrói uma narrativa tensa e lírica na mesma medida, que vive e morre por si, mudando pelo reflexo o olhar daquele que decide atravessá-la.

Largo as pás no chão. 


\section{Referências}

AZEVEDO, Estevão. Estevão Azevedo fala sobre seu romance "Tempo de Espalhar Pedras". Cosac Naify, São Paulo,18 set. 2014. Disponível em: https://www.youtube.com/watch?v=baSUJsn9g9k. Acesso em: 26 mar. 2020.

AZEVEDO, Estevão. Tempo de Espalhar Pedras. São Paulo: Cosac Naify, 2014.

AZEVEDO, Estevão. Nunca o Nome do Menino. Rio de Janeiro: Record. 2016.

BOSI, Alfredo. Dialética da colonização. São Paulo: Companhia das Letras, 1992.

CANDIDO, Antonio. Ficção e confissão. 3. ed. Rio de Janeiro: Ouro sobre Azul, 2006.

CHAUÍ, Marilena. Mito fundador e sociedade autoritária. São Paulo: Fundação Perseu Abramo, 2000.

GINZBURG, Jaime. O narrador na literatura brasileira contemporânea. Tintas. Quaderni di letterature iberiche e iberoamericane, n. 2, p. 199-221, 2012.

MARTINS, José de Souza. Linchamentos: a justiça popular no Brasil. São Paulo: Contexto, 2015.

PASSOS, José Luiz. Romance de Estevão Azevedo traz faces de um Brasil desumanizado. Estadão, São Paulo, 14 nov. 2014. Disponível em: http://cultura.estadao.com.br/noticias/literatura,romance-de-estevaoazevedo- traz-faces-de-um-brasil-desumanizado,1592944. Acesso em: 26 mar. 2020. 
PERRONE-MOISÉS, Leyla. A literatura exigente: os livros que não dão moleza ao leitor. Folha de São Paulo, Ilustríssima, 2012.

RAMOS, Graciliano. Vidas Secas. 25. ed. São Paulo: Editora Martins, 1970.

RESENDE, Beatriz. Possibilidades da nova escrita literária no Brasil. In:

RESENDE, Beatriz, FINAZZI-AGRÓ, Ettore (org.). Possibilidades da nova escrita literária no Brasil. Rio de Janeiro: Revan, 2014.

ROSA, Guimarães. Grande Sertão: Veredas. 19. ed. Rio de Janeiro: Nova Fronteira, 2001.

RUFFATO, Luiz. Alguns apontamentos sobre a literatura brasileira contemporânea. Conexões Itaú Cultural, 27 mai. 2013. Disponível em: http://conexoesitaucultural.org.br/biblioteca/alguns-apontamentos-sobre-aliteratura-brasileira-contemporanea/. Acesso em: 17 abr. 2020.

SCHØLLHAMMER, Karl Erik. Ficção Brasileira Contemporânea. Rio de Janeiro: Civilização Brasileira, 2009.

\section{Referência para citação deste artigo}

MALMACEDA, Ana Laura. Elementos para a interpretação de Tempo de Espalhar Pedras, de Estevão Azevedo. Revista PHILIA | Filosofia, Literatura \& Arte, Porto Alegre, volume 2, número 1, p. 2 - 25, junho de 2020. 